\title{
Distributive Leadership: Hierarchical Hegemonies and Policy challenges in African Schools
}

\author{
Icarbord Tshabangu \\ Dept. of Educational Foundations \& Managemen \\ University of Namibia, Private Bag 13301 \\ 340 Mandume Ndemufayo Ave, Pionierspark, Windhoek, Namibia \\ E-mail: preslica_012@hotmail.co.uk; itshabangu@unam.na
}

Received: Jan.1 3, 2013 Accepted: February 11, 2013 Published: February 11, 2013

doi:10.5296/jse.v3i1.3029 URL: http://dx.doi.org/10.5296/jse.v3i1.3029

\begin{abstract}
The paper examined notions of distributed leadership against cultural antecedents in engendering creativity and democratic school contexts, particularly in Africa, based on educational policies. Because schools are widely regarded as critical repositories of social and moral values, the paper interrogated the feasibility of achieving liberal democratic and cosmopolitan societies under the limiting frame of largely authoritarian and hierarchically hegemonic school cultures where teachers and school leaders often exercise unquestioned authority. The study thus investigated educators' perceptions on Distributed leadership, whose bedrock concentrates on the interactions rather than on actions of leaders and on the exercise of influence rather than authority, a concept which may engender a healthy culture of knowledge creation and sharing in a 21st century information age and a feature which is critical for learning institutions. Using an interpretive paradigm and critical discourse analysis, the study reviewed school organizational cultures through students' poetry, 10 interviews on Namibian educators and 60 semi structured questionnaires on Zimbabwean and Tanzanian school principals and teachers. Students' poetry showed the school contexts as functionalist and inhibitive to creativity and personal leadership development and this was further complemented by teachers' accounts which noted that school leadership was largely undistributed and perceived as a preserve for the school principal. The study's findings therefore noted immense cultural and structural challenges that continue to inhibit distributive leadership approaches thus impacting negatively on schools' ability to adapt to change and thus limit schools capacity to contribute meaningfully to the hyped about national goals.
\end{abstract}

Keywords: Distributed leadership, Hierarchical hegemony, Education, Policy, Africa 


\section{Introduction}

This article reports on challenges faced by most school principals in Sub Saharan Africa particularly on the application of distributive leadership approaches in schools. Distributed leadership is conceptualized as a tool that may broaden leadership influences and realize leadership potential in both learners and teachers, leading to a positive impact on educational outcomes (Harris 2008). Like in many other countries, Sub-Saharan Africa's expectation on leadership profile tends to aspire for inspirational, collaborative and not excessively self centered leaders (Northouse, 2010). Earlier studies on Distributed leadership have shown that remodeling and conceptualizing school leadership as fluid and constructed on the notion of multiplicity of leaders including teachers and learners has brought about success in some schools and higher levels of educational satisfaction (Spillane, Halverson \& Diamond, 2001; Spillane \& Diamond, 2007; Harris, 2008; Lumby, 2003).

In most African education systems there exist a conflictual disconnect where Ministries of Education have 'well-meaning' mission and vision statements particularly on producing skilled, critical thinking, creative and democratic citizens, (Namibia Ministry of Education [NME], 2012; UNESCO, 2001; Botswana Ministry of Education \& Skills Development [BMESD], 2012; South Africa Basic Education Department [SABED], 2012), yet the heavily bureaucratic and hierarchically hegemonic school cultures still obtain, with greater negation to adaptation and change and to the realization of national aspirations as embedded in vision and mission statements. This heavily hierarchic order runs contrary to the context of schools and education where there are rapid and unprecedented changes, which call for shared, collaborative, responsive and accountable leadership (Harris, 2008; Lumby, 2003). Aristotle once observed that "it is useless to have the most beneficial rules of society fully agreed on by all who are members of the polity if individuals are not going to be trained and have their habits formed for that polity” (as cited in Harber 1995, p. 1). The schools are widely regarded as critical repositories of social and moral values at national level (Gould, 1997; Garratt, 2011) and as such must engender leadership and cultural traits that are more likely to meet national aspirations such as Vision 2030 in Namibia (National Planning Commission Secretariat [NPCS], 2004), and Zimbabwe's vision 2020 (National Economic Planning Commission [NEPC], 1996).

It is observed that in the world over, organizations, including schools, have been built and studied on the basis of the concept of leaders directing others to fulfill a vision conceived and designed by them, but this paradigm has been challenged and knew epistemologies have emerged as Jackson noted that the eye at the top of the pyramid is often blind to the realities of the workplace below (as cited in Wepman, 1985). In education there has also been a gradual shift towards emphasis on educational leadership, which is seen as an exercise of influence rather than authority (Bush, Bell \& Middlewood, 2009). This notion is linked to contemporary epistemologies in distributed leadership (Harris 2008; Spillane \& Diamond, 2007), where there is loosening of formal roles within an organisation, thereby allowing those below the hierarchy, such as teachers and students, to exercise some level of power and influence. The study therefore sought to establish perceptions on Distributed leadership and whether as a tool, there is potential for its practice in schools so as to help achieve stated educational goals.

\section{Leadership and School Culture}

It is important to note that school organizational culture and leadership are two sides of the same coin and a strong link often exist between school cultures and academic performance 
(Stolp, 1994; Prosser, 1999; Lumby, 2003). School cultures and Leadership practices are therefore critical to educational outcomes considering that institutions are interactionist and laden with inter-personal relationships upon which success depends.

\section{Colonial Past and the Leadership Challenge}

The NME, (2012) for example states that when Namibia became independent in 1990, education in the country was best characterized by a fragmentation of education along racial and ethnic lines; unequal access to education and training at all levels of the education system; inefficiency in terms of low progression and achievement rates, and high wastage rates; Irrelevance of the curriculum and teacher education programmes to the needs and aspirations of individuals and the nation; and lack of democratic participation within the education and training system. It goes further to state that teachers, parents, administrators and workers were largely excluded from the decision-making process in education.

The characterization above depicts a cultural model of apartheid whose oxygenation was heavily rooted in a repressive hierarchical hegemony which negatively affected schools and resulted in impeded progress for the majority. In a new Namibia and elsewhere in Africa the question is to what extent do school principals' attitudes create a culture of distribution of power in their schools where every school member's leadership potential is valued and developed rather that demeaned and equated to "boy" status as under apartheid? It is noted that in most African school communities where paternalistic ideologies still obtain (Ncube, 1998; Indabawa, 1997) school practices are often submerged in a hierarchical hegemony whose cultures muzzle pupils' and teachers' creativity, leadership potential, democratic attributes thus adversely affecting national aspirations, despite beautiful Education mission statements that are a pointer to a cosmopolitan society (Osler \& Starkey, 2005).

For some in leadership, Tocqueville observed that, 'it is easy to issue commands and enforce them' (as cited in Wepman, 1985, p. 9). Submerged in anti-dialogism, issuing commands becomes an appealing option to those in authority because it does not only help them concentrate power in themselves (Polyarchy Organisation, 2003), but it also claims that it 'saves' time. It is noted that the notion of a passive subordinate, 'child-like' nature grows out of a twentieth century and western reconstruction and also out of pre-colonial and pre-capitalistic African societies which were heavily hierarchical. In both constructions, children and subordinates are to be seen not heard (Grier, 2006). But Berlin (1969) has argued that if the essence of Men is that they are autonomous beings - authors of values, of ends in themselves, then nothing is worse than to treat them as if they were not autonomous, but natural objects, played on by causal influences. Freire (1970) further commented that educators should socialize learners into active 'namers of the world' and not let others name the world for them. Some school leadership attitudes that are oppressive to the creative human spirit of teachers and students are non-congruent and anathema to national educational aspirations.

\section{The Heroic, Charismatic Principal Revisited}

It may be true that a school principal find a failing school and then turn it around in a short space of time and thus earn themselves a heroic status. What observers often forget in their haste to crown a principal heroic is the appreciation of how complex the art of school leadership is and that it may be near impossible for a single person to accomplish this 'mission impossible' (Spillane, 2005). Yukl (2009) has also argued that understanding leadership is not only arbitrary but subjective and laden with social influences. The distributive perspective in leadership does not focus on actions of one individual but at the 
leadership influence and shared practices. The school principal's role is multifaceted, consisting of public relations, project management, human and financial resource management, leadership, Curriculum and supervision, monitoring and Evaluation, pastoral care and so on. It is unthinkable that such roles can effectively be achieved by a single person without some level of distribution, which is not synonymous with delegation. In distributed leadership the issue is not about the principal's actions, for example in school public relation but how she influences that domain.

\section{Distributed Leadership and Theoretical Perspectives}

Leadership entails influencing others' actions in achieving desirable ends and leaders are people who shape the goals, motivations and actions of others (Cuban, 1988). Distributed Leadership has been explained by Spillane \& Diamond (2007) as founded on activity theory and distributed cognition. Activity theory is about how an activity system works (Bedny \& Meister, 1997) and this is comparable to the complex leadership activity. The activity of landing a plane is given as a classic example. This is where you have the pilots, the instrument panel and the people on the ground. The activity of landing the plane is not something an individual person does, nor done by an instrument panel without the people, or a pilot without the air traffic controller. On the other hand distributed cognition focuses more on social interaction, the context and artifacts in an environment where people's thinking and actions don't happen in a vacuum but through social and environmental interaction (Vygotsky, 1978; Crain, 1992; Hutchins, 1995). Distributed cognition impact how leadership activity occurs and Distributed leadership is seen as borne out of these integrated theories which helps us understand the complexity of leadership activities in schools. Distributed leadership is therefore a system of practice which comprises a collection of interactions; leaders, followers, and situation. These interactions must be understood together because the system is more than the sum of the parts or practices (Spillane, 2005).

\section{Distributed Leadership as Heterarchy}

Even though overlaps can be noted in leadership approaches, Distributed leadership cannot be equated to democratic leadership which is depicted as embodying the notion of 'upside down' institutions (Sallis, 1996). Nor is Distributed leadership similar to situational leadership where leadership is influenced by situations. On the contrary, Distributed Leadership is about how leadership influences situations (Spillane, 2005).

Michels (1962, p. 191) argued that 'bureaucracy is the sworn enemy of individual liberty and of all bold initiatives in matters of internal policy.' He further observed that in a bureaucratic, hierarchical state such as in some schools, once the leadership is established at the top of the bureaucratic pyramid, its primary concern is the maintenance of its own power. Leaders wish to retain the privilege and status which their position brings, a concern which takes priority over the stated goals of the organisation--whereby preservation of the organisation becomes an end in itself, rather than a means to an end. The bureaucratic, hierarchic systems are typically seen as petty, narrow, rigid and illiberal (Michels, 1962; Weber, 1996). Sometimes school authorities condone abuses by junior authority such as prefects as part of self-preservationist strategies (Tshabangu, 2010), since the preservation of the organisation would have become an end in itself (Michels, 1962).

Distributed leadership like Transformational leadership offers a humanistic approach defined by an open and empowering culture where communication, strong values and mutual respect are the norm (Clegg, 2000). Every team or individual sees itself as important and acts as an integral part in achieving stated organizational goals based on values (Cloke \& Goldsmith, 
2002). In such a culture, teachers' and students' participation in decision-making is valued and promoted. It is seen as a right and not a privilege. Such a structure is defined as heterarchy, as opposed to traditional hierarchy in management (Cloke \& Goldsmith, 2002). Heterarchy manifests itself where peers and different interest groups sharing power, are networked, and participate freely through self-management. For example, students may be allocated power to address and decide on issues pertaining to their halls of residence within agreed parameters and budgets.

The general trend has been that most of what happens within the schools is dictated by those higher up in the hierarchy, the 'hieros', which translates from Greek to mean the 'holy ones' (Cloke and Goldsmith, 2002, p. 83). Since in the religious frame then and now only a god is often seen as holy and unchallengeable, the hierarchical bureaucratic school is seen as founded on the notion of irrationality as noted by Popper (as cited in Bailey, 2000) and therefore promotes an unquestioning deference as seen in some African classrooms (Harber, 1995).

\section{Historical Glimpses of Distributive Leadership in African Education}

Even though distributive leadership may seem like a new approach some would argue that it is like old wine in new skins. Pupils of Morris Isaacson high school in Soweto once led an uprising against apartheid education in 1976, shocking their teachers by loudly singing "Nkosi Sikelel' iAfrika" (God Bless Africa), an African hymn that is now the South African national anthem. It is recorded that in those days, Morris Isaacson was a hotbed not only of radicalism but of academic excellence (Economist, 1999). It is further stated that the school produced revolutionaries, doctors and South Africa's only black nuclear physicist. By 1999 the school had become a shadow of its former self. Three-quarters of Morris Isaacson students failed to graduate and only 2\% made it to university (Economist, 1999). The problem was cited as not the lack of money but of leadership and a cultural break from the past. When visiting the school in 2004, the former vice-principal was recorded as saying "Morris Isaacson was a school that looked at improving the lot of every child in the school" (Joburg news, 2004). The "lot of every child" signify a distributive leadership approach that valued and natured individual potential to make own decisions.

In Namibia it is recorded that the private schools established during the colonial regime were called "Swapo" schools although they were private. "There was a big student and teacher uprising in 1976 in Gibeon against the Bantu Education System. Despite financial setbacks and the resultant dearth of textbooks, exercise books, stationary and lack of salaries for the staff, the school excelled (inamibia, 2012). It is noted that in both accounts the school leadership, despite political risks, created a culture where teachers' and students' leadership potential to independently influence situations was valued and practiced with positive outcomes academically and in attaining social justice. There is an African proverb, which says 'freedom and responsibility are two sides of the same coin.' What this means is that if a less free and highly structured and centralized authority exists even within a school, the environment is likely to inhibit creativity, lessen democratic values, demotivate teachers and learners and resultantly produce irresponsible citizens with poor skills and knowledge thus disadvantaging the inhabitants of that polity.

\section{Contemporary Glimpses of Distributive Leadership in African Education}

There is now an ever growing realisation that Leadership and influence should not necessarily reside only in the school principal but may exist in multiple contexts and persons within an organization (Spillane, 2005; Harris 2008). Without delegated authority, a teacher 
in South Africa went beyond the duties of the classroom to develop an 'Alternatives to Violence' programme to assist the youth at his Secondary School in dealing with violence in the classroom. He partnered with a pastor from the area (another distributive feature) to develop workshops called 'Alternatives to Violence', to mentor the boys and provide them with the life skills and self-esteem to help prevent gangsterism and violence. He was recorded as saying "These young men are natural leaders. The difference is that before they were leading in gangs and now they lead in a good way," (ED.ORG, 2008).

\subsection{Ikamva Youth Programme for Schools by University Students, South Africa}

It is recorded that most of the township high-school learners who join the programme, jump at least 2 or 3 symbols to access quality post-school opportunities when they matriculate. For the past 5 years, IkamvaYouth has achieved a matric pass-rate of between $85-100 \%$ and over $70 \%$ of IkamvaYouth learners have gained access to tertiary education (Ikamvayouth.org, 2012). A key feature of IkamvaYouth's achievements is a commitment to inclusive, value-based, but fluid and distributive decision-making processes where young independent university students take a lead (Ikamvayouth.org, 2012). Such leadership practices are marked by a shift from waiting for hierarchically rigid structures to provide solutions, to creating a fluid team based leadership environment that values and nurtures individual potential and contribution.

\subsection{Hero Awards (Pick and Pay School Club), South Africa}

Pick n Pay School Club of South Africa state that "there's a hero inside every one of us; within the school community, from the administration personnel, to the teachers and learners". Such assertions on leadership coupled with investments that promote distributive leadership attest to emergent notions that school leadership is complex and excellence may only be achieved through a distributive approach. As a result the Pick n Pay School Club has identified five categories to assist schools in selecting their heroes. The five categories are as follows: Leadership, Community upliftment, Sport, Overcoming hardship, Academic excellence (Pick n Pay School Club, 2012).

\subsection{The Education and Expedition Agency, Tanzania}

This agency has initiated official recognition of teachers as a fundamental foundation for quality education in Tanzania. This forms another feature which seeks to encourage teachers by recognizing personal initiatives in their field, thus benefit the wider community.

Previously, teacher innovations, especially in science were identified and innovators awarded nationally by science and technology committee. One primary school teacher in Morogoro region was recognized for pencil innovation using raw materials from a pigeon pea plant.

\section{Some International Trends on distributive school leadership}

In an effort to distribute school leadership to include particularly students, school ambassador programs now feature in several parts of the world. In the United Kingdom' primary schools for example, a few children are elected by other children in the school to be ambassadors. The main duties a school ambassador does include informing other children in their school about the Children's Commissioner; about children's rights and the United Nations Convention on the Rights of the Child and working with the school council, to find out what children in the school think could be improved (Childcom, 2012). In several schools particularly in the northern hemisphere, teachers working in teams or individually have taken up leadership on curricular issues with ability to make key decisions, a feature which was 
previously a preserve for school principals (Spillane \& Diamond, 2007; Harris, 2008 ).

\section{Methodology}

Following an Interpretive paradigm the study used Critical Discourse Analysis which is seen as aiding the attack against the power of global capitalism, bureaucracy and dominance over less powerful groupings (Fairclough, 2000). Discourse is often used to refer to patterns of meaning which organize various symbolic systems human beings inhabit (Parker, 1999), and which are necessary in making sense of their social world. Discourse analysis is therefore usually confined to speech and writing such as in transcribed interviews, and newspaper articles (Parker, 1999). Critical discourse analysis is largely founded on Marxist traditions in social theory that are interested in the relationship between language and ideology and ideas on political and economic dominance amongst groups in society (Travers, 2001). The study reviewed school organizational cultures through students' poetry; 10 interviews on Namibian educators and 60 semi structured questionnaires on Zimbabwean and Tanzanian school principals and teachers. These were analysed through coding and development of themes in relation to schools' micro-politics.

\section{Analytical Discussion}

After studying British secondary schools, Hardy cited in Harber (1995) compared their organisational style to prisons in that the inmates' routine is disrupted every 40 minutes; they change their place of work and supervisors constantly, are forbidden to communicate with each other. Similar environments of a carceral nature (Foucault, 1977) can still be witnessed in some African schools as noted in the poem below.

\subsection{Students Perceptions on School contexts}

Below are some of the students' poems which depict contexts in some schools.

\section{My school}

Another siren at 7: 45am [Control]

In straight rows according to our classes [Control]

It's now assembly; the choir gives us a hymn [Controlled voice]

Then the principal conducts the assembly [Control - no distribution]

It's another long day, being controlled by the siren. [Control]

The core business is to get education,

Subject after subject and exercises after tests, [Control]

Another subject, a test on the board, [Control]

The brain thinks till it bursts. [Wearied by the school machine]

Books are all over. [Overwhelmed]

That's my school. -By a student

The bureaucratic and mechanical system often operates through persuasion, coercion and sometimes force. Such may result in observable fear among those who rank lower in the hierarchy and often bear the brunt of the system's objectifying effects as exemplified in a 
student's poem below entitled 'They come in uniforms'.

They come in uniforms [Conformity]

In little groups, [Free outside school gate]

Rushing through the gate like birds chased from a tree [Fear]

The bell rings and the [Control]

Classroom fills [objectification]

Tired students hang their heads like leaves on a hot day [Wearied by the school machine]

Some look through the windows, [Yearn for freedom]

At the short, brown grass and the playing birds, [Birds as symbolising freedom outside]

At last the lessons are over, [Freedom]

They all rush home like rats

Chased by a cat, with curved empty stomachs [Objectification]

- By a student

Heavily centralized school structures turn to trap teachers and learners into an objectifying environment with no opportunity to contribute as to how educational processes should occur. Under a distributive leadership approach students and teachers are more likely to influence the cultural practices to the betterment of most learners in the school. Dahl (1989) once observed that most dictatorships, because of centralized power, invariably offer poor quality of life to their citizens as opposed to liberal nations. On Africa, Harber (1995) further commented that if dictatorship was instrumental for economic growth and quality lifestyles, Africa would be the richest continent, but unfortunately it is not.

Centuries ago, citizens were largely uneducated. Leaders often had a monopoly of information and thus Tolstoy (1894) records that leaders' often demanded or enforced obedience without question. In the 21st century where the media and technology has revolutionised education and modern democracy, such forms of leadership have become obsolete and a greater demand for shared and distributive leadership has taken root. It is now unthinkable that the role of a subordinate can only be limited to mere deference towards the leader.

\subsection{Principals and the Distributive Leadership Challenge}

Teachers and Education officers cited various challenges facing school principals and largely inhibiting distributive approaches in their school leadership.

\subsubsection{Skills and knowledge.}

This was cited among most principals as a key factor negatively impacting on the inability to distribute leadership. It is noted that in many parts of Africa most principals, are initially appointed as trained teachers who then reach the position of the principal through teaching rather than leadership experience resulting in principals resorting to the "trial-and-error" strategy once appointed. In Tanzania for example, the government introduced the primary education development plan (PEDP) in 2000 and afterwards the secondary education development plan (SEDP) in 2004, where communities participated in building more schools 
in their local areas. A lot of schools mushroomed giving rise to the need for school principals, which resulted in a large number of poorly skilled heads of schools. The key leadership challenge was cited as a lack in school human resources management of which distribution leadership was one.

\subsubsection{The fear factor.}

Even though in positions of power, principals have limited authority in the administration of schools due to weaker decentralization, as most Regional Education offices continue to wield immense power which may dwarf a principal's ability to exercise leadership distribution. In most Southern Afican leadership traditions "a king is a king because of his people” (Tyrell \& Jurgens 1983). This is not necessarily the case with most principal as they are more beholden to the appointing authority such as the regional offices and thus less responsive to school community needs. Teachers and students only become informed because the government would have insisted on the principals to involve stakeholders.

\subsubsection{Reclusivity.}

Most teachers reported that once appointed, most school principals tended to isolate themselves and listened less and less to subordinates as they perceived that others' ideas could be destructive of their leadership and that association may render them the tag of a weak leader.

\subsubsection{Leadership and development.}

It was noted that there were hardly any teachers or students who had initiated or were involved in exceptional educational projects. Those few were often not acknowledged by the leadership. Because of lack of recognition most of the students' and teacher's leadership potential fizzles out to the detriment of developing communities.

\subsubsection{Functionalism.}

The majority of school principals in Zimbabwe and Tanzania stated that teachers find that they have to focus on the school syllabus above all else. Because of the urge to succeed in examinations, some principals observed that both students and teachers tended to 'live under commands' and that the school system was largely examination centered. These functionalist views presented the school contexts as illiberal (Berlin, 1969) and thus possibly unable to exercise leadership distribution which is fluid and may involve risk and experimentation.

\subsubsection{Rigidity.}

Many School principals tended to shy away from teaching responsibilities citing their headship role. Such a trend may presuppose that principals are less likely to promote a culture of leadership distribution as they see teachers and students as encroaching into their sphere. From this perspective, leadership becomes only associated with the school principal.

\subsubsection{Delegation and distribution.}

A brief study in the Caprivi Region of Namibia concluded that most principals tended to practice delegation rather than distribution, noting that principals were often in the forefront in most aspects of school administration. This may have led to few learners and teachers who could be identified as having done 'heroic' leadership deeds in education. Only one teacher was recorded as having won awards in Mathematics on several occasions having gone outside the call of duty to do extra free teaching on holidays and weekends thus ensuring an 
excellent Mathematics pass rate for his school in the region. In the exception of Learner Representative Councils, which are required by some Education Acts as in Namibia, most schools continued to provide no leadership development spaces for both learners and teachers.

\subsubsection{Partnerships.}

Due to lack of a distributive leadership approaches many schools still lacked partnerships and associations between schools was commented upon as weak by most teachers, except only in areas such as sports. It is noted that while years ago a lot of schools seemed to operate in isolation, the emerging trends are of networked schools linked to various agencies, associations and organizations (Harris, 2008).

\subsubsection{Managerialism and Leadership.}

Several school principals did not regard themselves as leaders but managers caged under hierarchical influences of handed down policies. This is despite the fact that a number of these school principals make daily decisions of a leadership nature such as influencing staff motivational levels and determining priority areas in their schools. Such a conception of leadership is contrary to emerging trends in educational Management and leadership where responsibilities and activities are dispersed or distributed across a range of people and contexts (Lumby, 2003; Harris, 2008; Spillane \& Diamond, 2007; Bush, Bell \& Middlewood, 2009).

\section{A distributive model for schools}

Distributed Leadership allows for everyone to be responsible and accountable within their remit as staff and students cooperate in creating change within an environment where everyone's ideas are valued and leadership capacities strengthened (West Chester University, 2012). The adaptable distributive model presented below is not prescriptive as each school context is unique, but provides a framework to engender distributive leadership attitudes. The distributive leadership culture in an organisation may therefore entail the following;

Does not mean delegating. Instead, it means finding the best path by tapping the expertise, ideas, and effort of everyone involved

Brings success in handling problems, threats, and change

It not only encourages idea sharing, it demands it.

Can look for better ways and test them through controlled, reasoned risk taking

Environment, mistakes often lead to discovering valuable new approaches.

Not everyone is a decision-maker, but everyone is an expert who contributes to the decision-making process.

Not for mavericks and lone eagles

Cooperation and trust, not competition among units

Share the same mission, even though we contribute to it in different ways

Empowers everyone to make his or her job more efficient, meaningful, and effective

Everybody matters 


\section{Conclusions}

This study examined the conflictual nature of educational policy and school practices, particularly the lack of alignment between these. Most school leadership practices were found to be still heavily hierarchic in nature and showed a lack of capacity to adapt to developmental changes in education and to respond to prescribed national visionary goals. These findings concur with other studies in other parts of the world such as Lumby, (2003)'s assessment of some further education colleges in England. The study established that teachers and learners still find themselves in school contexts that suppress and inhibit their full leadership potential. Even though the bureaucratic and hierarchically hegemonic cultures may have given these education systems some 'good' schools, it seems unlikely that the future demands in education will be satisfied by just -'good' schools. Technological advancement in all spheres of life and the awakening of those whose rights have been downtrodden may be better served by less rigid and less hierarchical educational contexts where distributive approaches throughout the school system are a norm. The study has been significant in that in mirrored Distributed leadership against African perspectives and posited it as a leadership tool and an attitude that may usher in a new organizational culture which helps broaden the sphere of leadership within schools such that creativity and democratic values are allowed to flourish resulting in improved micro and macro-political outcomes in the knowledge economy of a nation.

\section{References}

Bailey, R. (2000). Teaching Values and Citizenship. London: Sage

Bedny, G. \& Meister, D. (1997). The Russian Theory of Activity: Current Applications to Design and Learning. London: Psychology Press.

Berlin, I. (1969). Four Essays On Liberty. London: Oxford University Press.

Botswana Ministry of Education \& Skills Development. (2012). 'e Information and $e$ Service' Retrieved May 18, 2012, from http://www.gov.bw/en/Ministries--Authorities/Ministries/Ministry-of-Education-MoE/

Bush, T., Bell, L. \& Middlewood, D. (Eds.). (2009). The Principles of Educational Leadership and Management. London: Sage.

Childcom. (2012). School Ambassadors. Retrieved May 18, 2012, from http://www.childcom.org.uk/en/school-ambassadors/

Clegg, A. (2000). Leadership: Improving the quality of patient care. Nursing Standard, 14(30), 43-45.

Cloke, K. \& Goldsmith, J. (2002). The end of management and the rise of organisational democracy. San Francisco: Jossey-Bass.

Crain, W. (1992). Theories of Development. New Jersey: Prentice Hall.

Cuban, L. (1988). The Managerial Imperative and the Practice of Leadership in Schools, , Albany :State University of New York Press

Dahl, R. A. (1989). Democracy and its Critics. New Haven: Yale University Press.

Economist. (1999). Heroes into dunces. Retrieved May 15, 2012, from http://www.economist.com/node/204144 
ED. (2008). Teacher Recognised for Taking the Lead: Stars in Education Awards. Retrieved April 06, 2012, from http://www.ed.org.za/index.php/teachers/138-2008-teacher-recognised-for-taking-the-lead-sta rs-in-education-awards

Fairclough, N. (2000). Language and Neo-liberalism. Discourse and Society, 11(2). 1-2.

Gould, W.T.S. (1993). People and Education in the Third World. New York: Longman.

Foucault, M. (1977). Discipline and punish: The birth of the prison. London: Penguin Books. http://dx.doi.org/10.1177/0957926500011002001

Freire, P. (1970). Pedagogy of the Oppressed. London: Penguin.

Garratt, D. (2011). Equality, difference and the absent presence of 'race' in citizenship education in the UK', London Review of Education, 9(1). 27 - 39.

Grier, B. C. (2006). Invisible Hands: Child labour and the State in Colonial Zimbabwe. Portsmouth: Heinemann.

Harber, C. (1995). Developing Democratic Education. Derby: Education Now Books.

Harris, A. (2008). Distributed School Leadership: Developing tomorrow's leaders, London: Routledge.

Hutchins, E. (1995). Cognition in the Wild. Cambridge, MA: MIT Press.

Indabawa, A.S. (1997). Pupil's autonomy, cultural hegemony and education for democracy in an African society in D. Bridges (Ed.), Education, autonomy and democratic citizenship: Philosophy in a changing world. London: Routledge.

Joburg news. (2004). Morris Isaacson's stars go back to school. Retrieved May 18, 2012, from http://www.joburgnews.co.za/2004/july/july27_reunion.stm

Lumby, J. (2003). Culture Change: The Case of Sixth Form and General Further Education. http://dx.doi.org/10.1177/0263211X0303102104

Colleges. Educational management and administration. 31(2). 159-174.

Michels, R. (1962). Political Parties. New York: The Free Press.

inamibia. (2012). The Liberation Struggle from within Namibia. Retrieved May 20, 2012, from

http://www.inamibia.co.na/news/local/item/15141-the-liberation-struggle-from-within-namib ia.html

Namibia Ministry of Education. (2012). About the Ministry of Education. Retrieved May 12, 2012, from' http://www.moe.gov.na/m_ab_aboutus.php

Namibia National Planning Commission Secretariat. (2004). Vision 2030. Windhoek: National Planning Commission.

Ncube, W. (1998). (Eds.). Law, culture, tradition and children's rights in eastern and southern Africa, Aldershot: Ashgate.

Northouse, P. G. (2010). Leadership ( $5^{\text {th }}$ ed.). London: Sage

Osler, A. \& Starkey, H. (2005). Changing Citizenship: Democracy and Inclusion in 
Education. Maidenhead, Berks: Open University Press.

Parker, I. (1999). Critical textwork: Introduction to varieties of discourse and analysis. Buckingham: Open University Press.

Patterson, J. L. (1993). Leadership for Tomorrow’s Schools. Alexandria: ASCD.

Pick n Pay School Club. (2012). Hero Awards, Retrieved May 22, 2012, from http://www.schoolclub.co.za/HeroAwards/Introduction.aspx

Polyarchy Organisation. (2003). Polyarchy; a paradigm. Retrieved April 2, 2002, from http: //www.polyarchy.org/paradigm/english/democracy.html

Prosser, J. (1999). The evolution of school culture research in J. Prosser (Ed.), School culture, London: PCP Ltd. http://dx.doi.org/10.4135/9781446219362.n1

South Africa Basic Education Department, 2012),

Spillane, J., Halverson, R. \& Diamond, J. (2001). Investigating School Leadership and Practice: A Distributed Perspective, Research News and Comments (April): 23-7.

Spillane, J.P. (2005). Distributed Leadership. The Educational Forum, 69, 143. http://dx.doi.org/10.1080/00131720508984678

Spillane, J.P. \& Diamond, J.B. (Eds.) (2007) Distributed Leadership in Practice, New York: Teachers College Press.

Stolp, S. (1994). Leadership for school culture, Education Management, 91, 1-5.

Tolstoy L.N. (1894). On Patriotism, Retrieved May 22, 2009, from http: //www.panarchy.org/tolstoy/189

Travers, M. (2001). Qualitative Research through Case Studies. London: Sage.

Tshabangu, I. (2010). Democratic Citizenship Education: A qualitative research journey in Zimbabwe. London: Lambert Academic Publishing.

Tyrell, P. \& Jurgens B. (1983). African Heritage, London: Macmillan Press.

UNESCO. (2001). The Developments in Education: The Education System at the end of the 20th Century - A National Report of the Republic of Zimbabwe, Unesco Bureau of International Education. Retrieved May 22, 2007, from http: //www.ibe.unesco.org/International/ICE/natrap/Zimbabwe.pdf

Vygotsky, L. S. (1978). Mind in society: The Development of higher psychological processes. Massachusetts: Harvard University Press.

Weber, M. (1996). The Protestant Ethic and the Spirit of Capitalism. London: Routledge

Wepman, D. (1985). Jomo Kenyatta. London: Burke Publishing Co. Ltd.

West Chester University. (2012). Introduction to Distributed Leadership. Retrieved May 22, 2012, from http://www.wcupa.edu/scripts/vacancies/distlead.asp

Yukl, G. A. (2009). Leadership in Organisations (7th Ed.). Upper Saddle River, NJ: Prentice-Hall.

Zimbabwe National Economic Planning Commission. (1996). Zimbabwe Vision 2020 and 


\section{Macrothink}

Journal of Studies in Education

ISSN 2162-6952 2013, Vol. 3, No. 1

Long-term Development Strategies. Retrieved July 20, 2010, from http://books.google.com.na/books?id=gS15QwAACAAJ\&dq=Zimbabwe+National+Econom ic+Planning+Commission+vision+2020\&hl=en\&sa=X\&ei=NzfHT7mXIImphAev3rWxCw\& ved=0CEsQ6AEwAw 